\title{
NOTE ON THE ELECTRICAL RESISTANCE OF CONTACTS BETWEEN NUTS AND BOLTS
}

\author{
By Frank Wenner, G. W. Nusbaum, and B. C. Cruickshanks
}

\section{ABSTRACT}

Measurements were made of the electrical resistance between nuts and bolts, using two radically different types of threads, the American National and the Dardelet, and different materials. The test specimens were three-fourths inch bolts of copper, brass, bronze, and steel with nuts of the same materials. The resistances between nuts and bolts were measured with stresses in the bolts, applied by turning the nuts, in the range from near zero to well toward the elastic limit of the materials. It was found that the contact resistance is usually less than a 1-inch length of bolt and that under similar conditions the resistance of the Dardelet thread is, in general, not more than one-fourth that of the American National thread. The maximum resistances found were for steel bolts having the American National thread. For these with a stress of 2,000 lbs./in. ${ }^{2}$ in the bolts the resistance is about 10 microhms, which is the resistance of about an inch length of the bodies of the bolts. The minimum resistances found were for copper bolts having Dardelet threads. For these, with a stress of 6,000 or more lbs./in. ${ }^{2}$ in the bolts, the resistance is of the order of 0.02 microhm which is the resistance of about one sixty-fourth inch length of the bolts.

\section{CONTENTS}

I. Introduction

II. Description of screw threads used

III. Method of measurement

IV. Test specimens..... 759

V. Apparatus

VI. Procedure

VII. Discussion of results

VIII. Acknowledgments

IX. Conclusions

\section{INTRODUCTION}

Every piece of electrical equipment requires some sort of connections between various parts of a circuit. To facilitate assembly, the connections are often made by means of bolts or machine screws. When the construction is such that the bolt and nut, or other threaded device forms a part of the electric circuit, the electrical resistance of such contacts is of more or less importance, depending upon the nature of the apparatus, and little, if any, definite information on the subject is available.

The purpose of this investigation was to measure the resistance of such contacts when made through different types of threads in different materials and with different stresses in the bolts or screws. The types of thread selected were the American National coarse thread and the Dardelet thread. The materials selected were steel, brass, bronze, and copper; and the stresses in the bolts ranged from near zero well up toward the elastic limit of the materials.

\section{DESCRIPTION OF SCREW THREADS USED}

The American National form of thread (formerly the United States Standard thread) is so well known that a description is unnecessary. A cross section of this thread is shown in Figure 1 and with the nut only in section in Figure 2. 
The Dardelet thread is comparatively new so it will be described somewhat in detail. Figure 3 shows the nut in a position which it may take with no tension in the bolt. In this position the nut turns freely on the bolt. Figure 4 shows the nut in the position which it takes with the working tension in the bolt. In this position

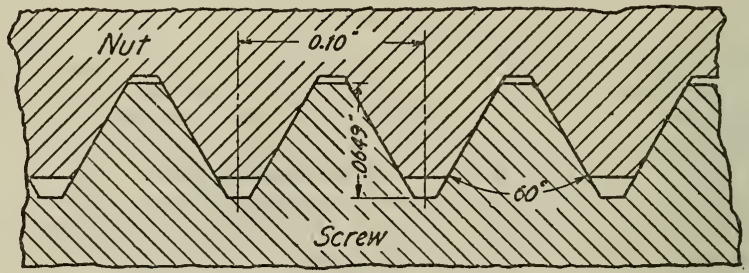

Figure 1.-Section of the American National form of coarse thread, formerly known as the United States Standard thread

the nut is locked to the bolt. The inclinations of the sides are the same as the Acme thread. The surfaces at the major diameters are cylindrical with clearance between the bolt and nut. The surfaces at the minor diameters are helical cones.

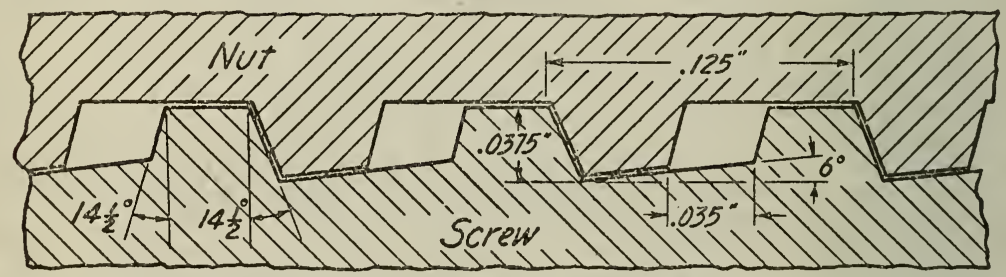

FIGURE 5.-Detailed section of the Dardelet thread with nut in free position on the screw

When the nut is screwed on the bolt, there is clearance between the threads of the two pieces, as shown in Figure 3 and also in Figure 5. When the nut is screwed down by hand into contact with the parts to be clamped, the helical cones come into contact. As the nut is turned to increase the tension in the bolt, the helical cones are

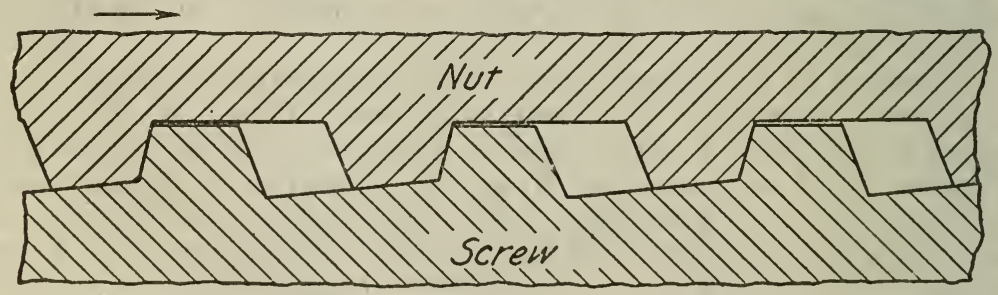

FIGURE 6.-Detailed section of Dardelet thread with the locking cones compressed and the thrust faces in contact

compressed elastically until the thrust faces come into contact as shown in Figures 4 and 6 . The load on the bolt is then sustained largely by the thrust faces of the threads, and the tapered surfaces at the minor diameter of the threads are highly compressed. It is this close contact which resists the backing off of the nut, even though the tension in the bolt be released. 
B. S. Journal of Research, RP227

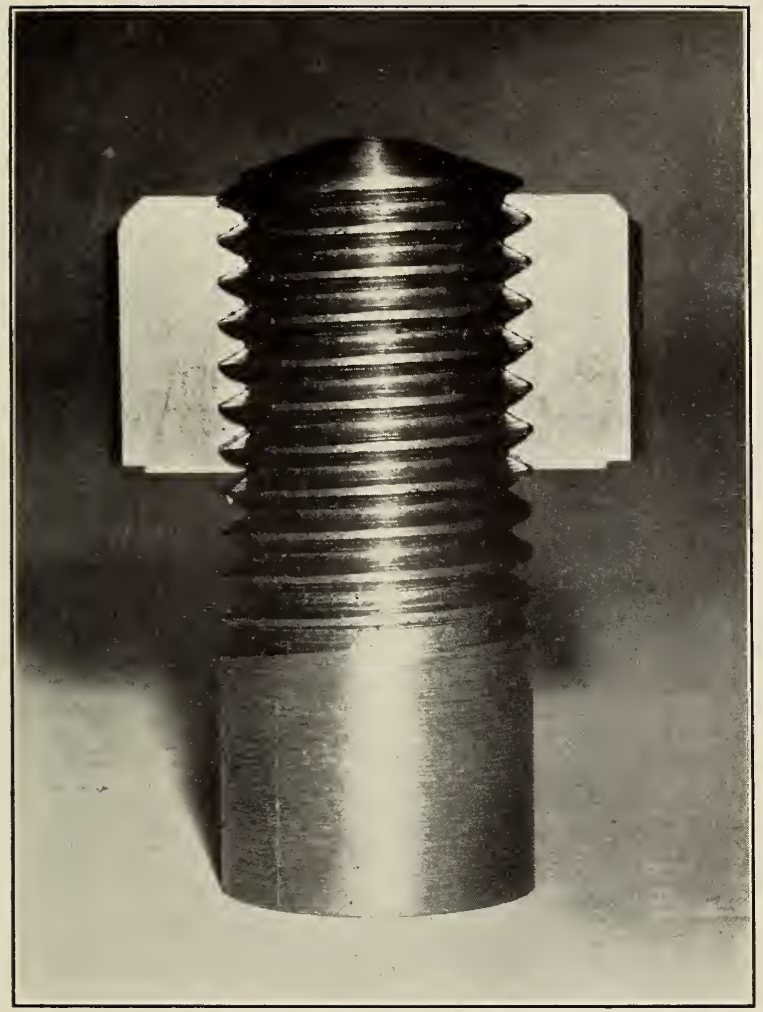

Figure 2.-The A merican National form of coarse thread with nut only in section 


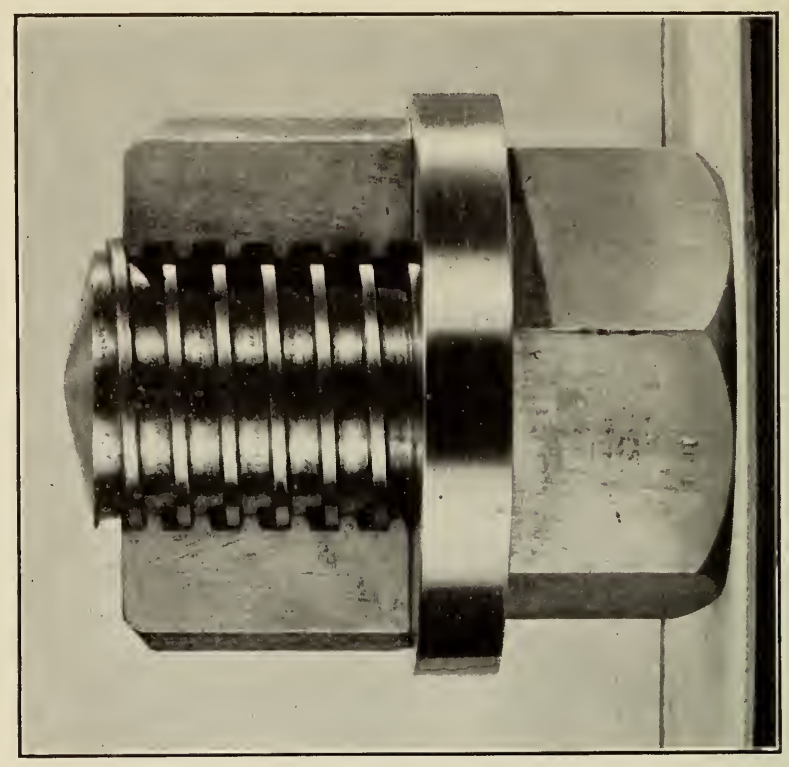

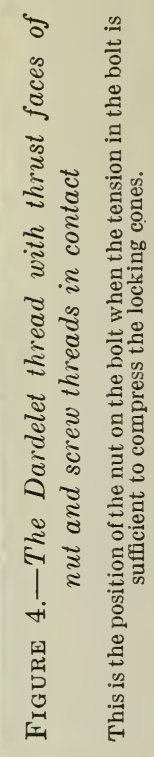

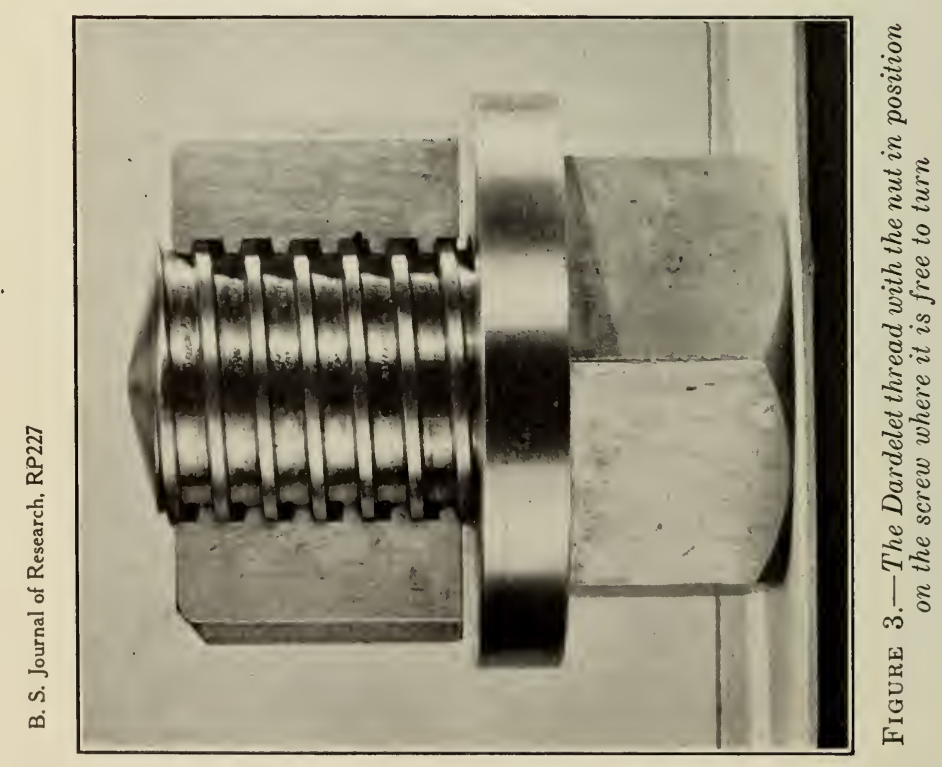




\section{METHOD OF MEASUREMENT}

The measurements were made by passing current from the nut to the bolt and comparing the drop in potential from the nut to the bolt with the drop in potential across a known resistance in the circuit. The comparisons were obtained from the relative deflections of a galvanometer when connected alternately to the nut and bolt and across the known resistance. The relative resistances were considered to have the same ratio as the relative deflections of the galvanometer when corrected for the different sensitivities which it was found necessary to use in order to include the wide range in values found. Precautions were taken to obtain an accuracy sufficient for the purpose.

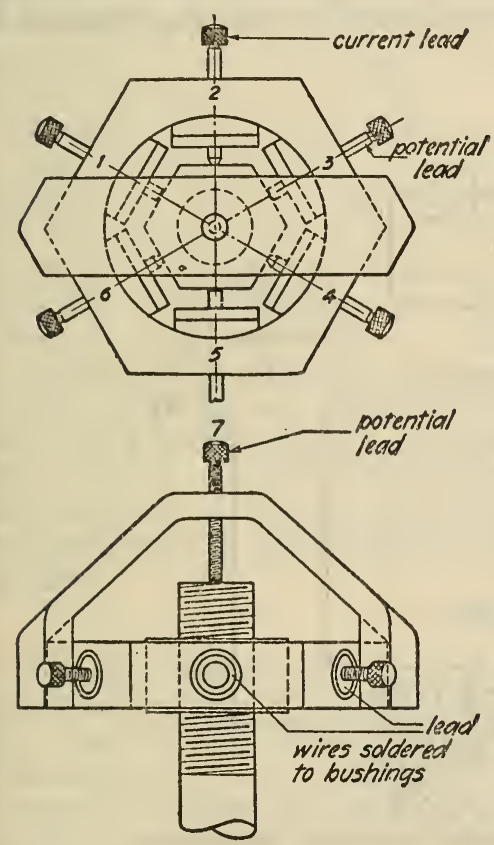

(a)

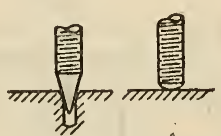

Current Potential

(b)

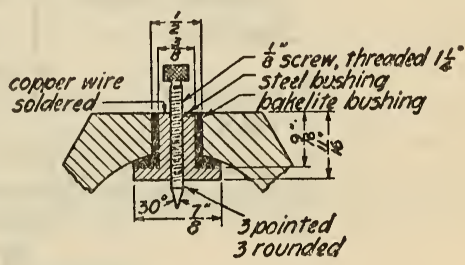

(c)

Figure 7

$a$, General arrangement of jig for current and potential connections.

$b$, Contact details.

c, Sectional view of contact screw insulation.

\section{TEST SPECIMENS}

The bolts for the test specimens consisted of three-fourths inch rods of machine steel, brass, bronze, and copper. These were threaded in accordance with commercial practice, American National coarse threads at one end and Dardelet threads at the other. The nuts of steel, copper, and brass were all of the same size, thirteen-sixteenths inch thick and 11/16 inches across flats. The bronze nuts were thirteensixteenths inch thick and $1 \frac{1}{8}$ inches across flats. The nuts, also, were threaded in accordance with commercial practice. In addition, there was one specimen of machine steel similar in shape to the other test specimens, but made from one piece so as to have no resistance between the part corresponding to the bolt and the part corresponding to the nut. This will hereafter be referred to as the one-piece specimen. Each nut had three holes drilled to a depth of slightly more than one-eighth inch and reamed, as shown in Figure $7(b)$. These were 
centered on alternate faces of the nut and served for definitely locating the electrical connnections.

\section{APPARATUS}

All electrical connections on the nuts were made by means of the jig shown in Figure $7(a)$. Six radial screws entered steel bushings insulated, by bakelite bushings, from the body of the jig as shown in Figure $7(c)$. Figure $7(b)$ shows details of the screw contacts with the nut. Three screw points entered holes drilled in the three nonadjacent sides of the nut, and the other three screw ends made contact on the flat surfaces of the intermediate sides. The leads from screws 1,3 , and 5 were connected to conductors of equal resistance and these conductors connected together to constitute the current terminal for

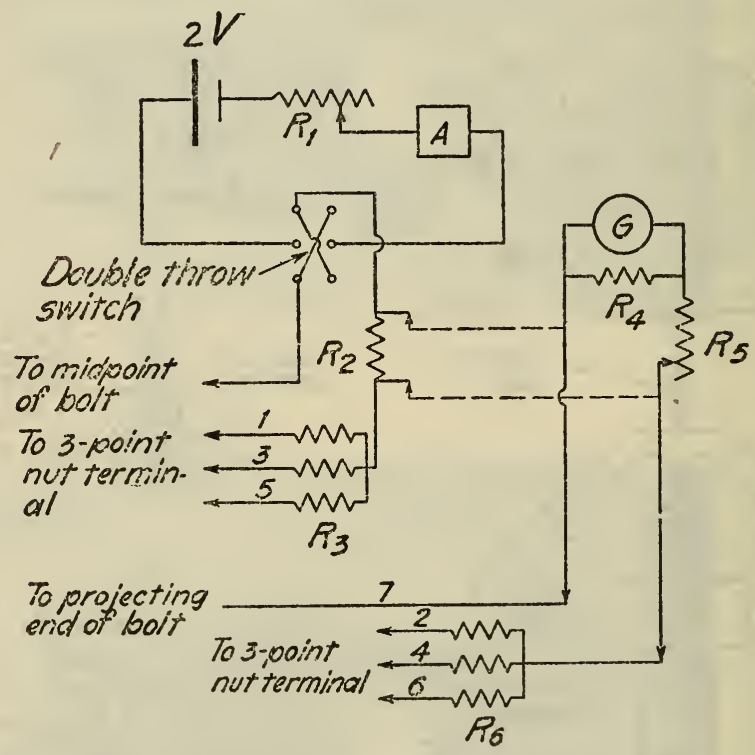

FIgURE 8.-Wiring diagram for nut-to-bolt resistance tests

the nut. The bolt current terminal (not shown) was made at the middle of the bolt. The leads from screws 2,4 , and 6 were connected to conductors of equal resistance, and these conductors connected together to constitute the nut potential terminal. Screw 7 constituted the bolt potential terminal. The use of branched current and potential terminals on the nut makes the resistance the same as the average which would be obtained from measurements made with the current connection first on one and then on another of the alternante faces of the nut, and for each of these three positions of the current terminal with the potential terminal first on one and then on another of the intermediate faces of the nut. Thus a single measurement gives the average of what would be obtained in nine separate measurements without branched current and potential terminals.

The arrangement of the electric circuit is shown in Figure 8. Here $R_{1}$ is an adjustable resistance for regulating the current; $R_{2}$ is a 
constant resistance whose value was determined by comparison with a resistance standard and used as a reference standard; $R_{3}$ represents three conductors of equal resistance, one in each branch of the threepoint current terminal to ensure a uniform distribution of the current between the three alternate faces of the nut; $R_{4}$ is a resistance used to properly damp the galvanometer; $R_{5}$ is an adjustable resistance for varying the sensitivity of the galvanometer; $R_{6}$ represents three conductors of equal resistance, one in each branch of the three-point potential terminal, to obtain the mean potential on the three faces of the nut between those faces on which the current is led into the nut. This arrangement constitutes a four-terminal resistance including the contact between the nut and bolt, but only a very small amount of the material of the specimen. The resistance of the material included was determined in a manner to be explained later and applied as a correction to the measured resistance to get the resistance of the contact between nut and bolt.

The test current was supplied by a two-volt storage cell and adjusted by means of the rheostat $R_{1}$ to the desired value, as indicated by the ammeter $A$. The double throw switch served for closing the circuit with the polarity of the battery in either direction. The resistance $R_{5}$ served to change the sensitivity of the galvanometer $G$, that is, the deflection of the galvanometer for a given potential drop in $R_{2}$, or across the nut and bolt, so that the deflections would be neither completely off the scale nor too small for reasonably accurate readings. A screw type testing machine served to measure the tension in the bolt, and a hand wrench served to apply this tension and at the same time slide the contact to simulate the usual procedure in the assembling of such electrical connections. The nut was supported on an insulated plate to avoid a short circuit through the frame of the testing machine.

\section{PROCEDURE}

With the threads well oiled, the nut resting on the insulated plate supported by the upper head and the bolt gripped by jaws in the lower head of the testing machine, measurements of the resistance were made according to the method outlined above for each increment of stress $\left(2,000 \mathrm{lbs}\right.$. $/$ in. $\left.{ }^{2}\right)$ in the bolt. The range of stresses used extended from practically zero to 16,000 lbs./in. ${ }^{2}$ for the copper, brass, and bronze specimens, and to $20,000 \mathrm{lbs}$./in. ${ }^{2}$ for the steel specimens. The stresses were calculated for a diameter corresponding to that at the root of the threads. To increase the load, it was necessary to remove temporarily the jig carrying the branched current and potential terminals. Measurements of the resistance were made only after an increase in the stress, except for the initial resistance. With the specimen merely placed in position, the resistance was found to be rather high and very indefinite. Before measuring the initial resistance the nut was turned with one hand while a downward pull was exerted on the bolt by the other hand. Then with the load reduced to merely the weight of the bolt, which was considered zero stress in the bolt, the resistance was found to be sufficiently definite to permit of measurement.

Two specimens of each of the four materials were used, and since each specimen had American National coarse threads on one end and Dardelet threads on the other, 16 sets of values were obtained.

$4754^{\circ}-30-17$ 
The resistance of the one-piece specimen was measured with the same arrangement of current and potential terminals used in the measurements of the resistance between nut and bolt. The resistance of a 4-inch length of one bolt of each of the four materials was also measured, from which the relative conductiveness of the four materials could be found. In the latter measurements single-current leads were clamped near the ends of the bolt, while potential connections were made by means of knife-edges attached to a spacer of insulating material and pressed lightly against the side of the bolt. From the measured resistance of the one-piece specimen and the relative conductivities of the materials, the resistances of one-piece specimens of the other materials were calculated. The values for one-piece specimens found in this way were subtracted from the measured resistance of the nut and bolt specimens and the differences considered to be the resistances of the contacts between the nuts and bolts. The results obtained are given in Tables 1 to 4 and except for zero stress are shown graphically in Figures 9 and 10. Figure 9 gives the results for the two steel specimens plotted separately. This gives a fair idea of the agreement of the measurements on duplicate specimens. Figure 10 gives the resistances for all materials plotted to a different scale from that used in Figure 9 and here each point represents the average of the values obtained for the two specimens.

TABLE 1.-Contact resistance between nut and bolt

\begin{tabular}{|c|c|c|c|c|c|c|}
\hline \multirow{3}{*}{ Stress in bolt } & \multicolumn{6}{|c|}{ Contact resistance } \\
\hline & \multicolumn{3}{|c|}{ American National thread } & \multicolumn{3}{|c|}{ Dardelet thread } \\
\hline & $\begin{array}{l}\text { Steel } \\
\text { specimen } \\
\text { No. } 1\end{array}$ & $\begin{array}{c}\text { Steel } \\
\text { specimen } \\
\text { No. } 2\end{array}$ & Average & $\begin{array}{l}\text { Steel } \\
\text { specimen } \\
\text { No. } 1\end{array}$ & $\begin{array}{l}\text { Steel } \\
\text { specimen } \\
\text { No. } 2\end{array}$ & Average \\
\hline $\begin{array}{l}\quad \text { Lbs./in. }{ }^{2} \\
0,000 \\
4,000 \\
6,000 \\
8,000 \\
10,000\end{array}$ & $\begin{array}{c}\text { Michroms } \\
300.4 \\
7.48 \\
3.96 \\
3.00 \\
2.40 \\
1.74\end{array}$ & $\begin{array}{c}\text { Michroms } \\
301.9 \\
9.31 \\
5.47 \\
3.90 \\
3.26 \\
2.84\end{array}$ & \begin{tabular}{|c|} 
Michroms \\
301.2 \\
8.40 \\
4.72 \\
3.45 \\
2.83 \\
2.29
\end{tabular} & \begin{tabular}{|c} 
Michroms \\
353.4 \\
1.21 \\
.635 \\
.402 \\
.30 \\
.25
\end{tabular} & $\begin{array}{c}\text { Michroms } \\
49.7 \\
1.34 \\
.82 \\
.63 \\
.47 \\
.39\end{array}$ & $\begin{array}{c}\text { Michroms } \\
201.5 \\
1.28 \\
.73 \\
.52 \\
.39 \\
.32\end{array}$ \\
\hline $\begin{array}{l}12,000 \\
14,000 \\
18,000 \\
18,000\end{array}$ & $\begin{array}{r}1.45 \\
1.17 \\
.92 \\
.89 \\
.59\end{array}$ & $\begin{array}{l}2.30 \\
1.81 \\
1.66 \\
1.44 \\
1.31\end{array}$ & $\begin{array}{r}1.88 \\
1.49 \\
1.29 \\
1.17 \\
.95\end{array}$ & $\begin{array}{l}.28 \\
.21 \\
.22 \\
.18 \\
.17\end{array}$ & $\begin{array}{l}.28 \\
.27 \\
.29 \\
.29 \\
.22\end{array}$ & $\begin{array}{l}.28 \\
.24 \\
.25 \\
.24 \\
.19\end{array}$ \\
\hline
\end{tabular}

TABLE 2.-Contact resistance between nut and bolt

\begin{tabular}{|c|c|c|c|c|c|c|}
\hline \multirow{3}{*}{ Stress in bolt } & \multicolumn{6}{|c|}{ Contact resistance } \\
\hline & \multicolumn{3}{|c|}{ American National thread } & \multicolumn{3}{|c|}{ Dardelet thread } \\
\hline & $\begin{array}{l}\text { Bronze } \\
\text { specimen } \\
\text { No. } 1\end{array}$ & $\begin{array}{l}\text { Bronze } \\
\text { specimen } \\
\text { No. } 2\end{array}$ & Average & $\begin{array}{c}\text { Bronze } \\
\text { specimen } \\
\text { No. } 1\end{array}$ & $\begin{array}{c}\text { Bronze } \\
\text { specimen } \\
\text { No. } 2\end{array}$ & Average \\
\hline $\begin{array}{l}\quad \text { Lbs./in.2 } \\
0,000 \\
4,000 \\
6,000 \\
8,000\end{array}$ & $\begin{array}{c}\text { Michroms } \\
28.17 \\
1.34 \\
.86 \\
.60 \\
.45\end{array}$ & $\begin{array}{c}\text { Michroms } \\
61.57 \\
1.69 \\
.82 \\
.58 \\
.51\end{array}$ & $\begin{array}{c}\text { Michroms } \\
44.87 \\
1.51 \\
.84 \\
.59 \\
.48\end{array}$ & $\begin{array}{c}\text { Michroms } \\
17.59 \\
.35 \\
.154 \\
.132 \\
.116\end{array}$ & $\begin{array}{c}\text { Michroms } \\
31.77 \\
.45 \\
.186 \\
.127 \\
.127\end{array}$ & $\begin{array}{c}\text { Michroms } \\
24.68 \\
.40 \\
.17 \\
.130 \\
.122\end{array}$ \\
\hline $\begin{array}{l}10,000 \ldots \\
12,000 \ldots \\
14,000 \ldots \\
16,000 \ldots\end{array}$ & $\begin{array}{l}.33 \\
.31 \\
.239 \\
.239\end{array}$ & $\begin{array}{l}.38 \\
.32 \\
.31 \\
.257\end{array}$ & $\begin{array}{l}.355 \\
.315 \\
.274 \\
.248\end{array}$ & $\begin{array}{l}.089 \\
.099 \\
.089 \\
.078\end{array}$ & $\begin{array}{l}.100 \\
.110 \\
.110 \\
.100\end{array}$ & $\begin{array}{l}.095 \\
.105 \\
.10 \\
.089\end{array}$ \\
\hline
\end{tabular}




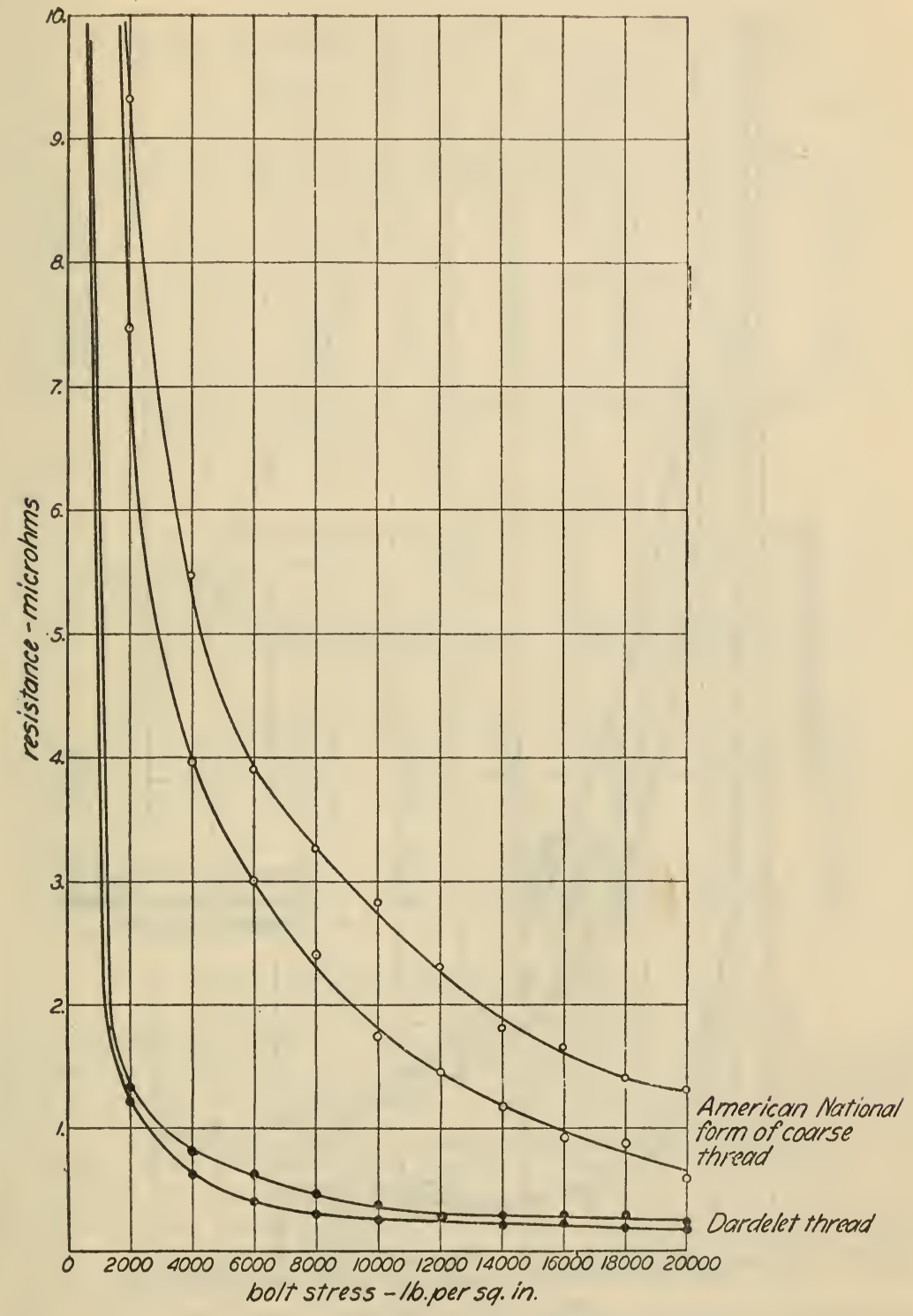

Figure 9.-Nut-to-bolt resistance tests on steel (two specimens) 


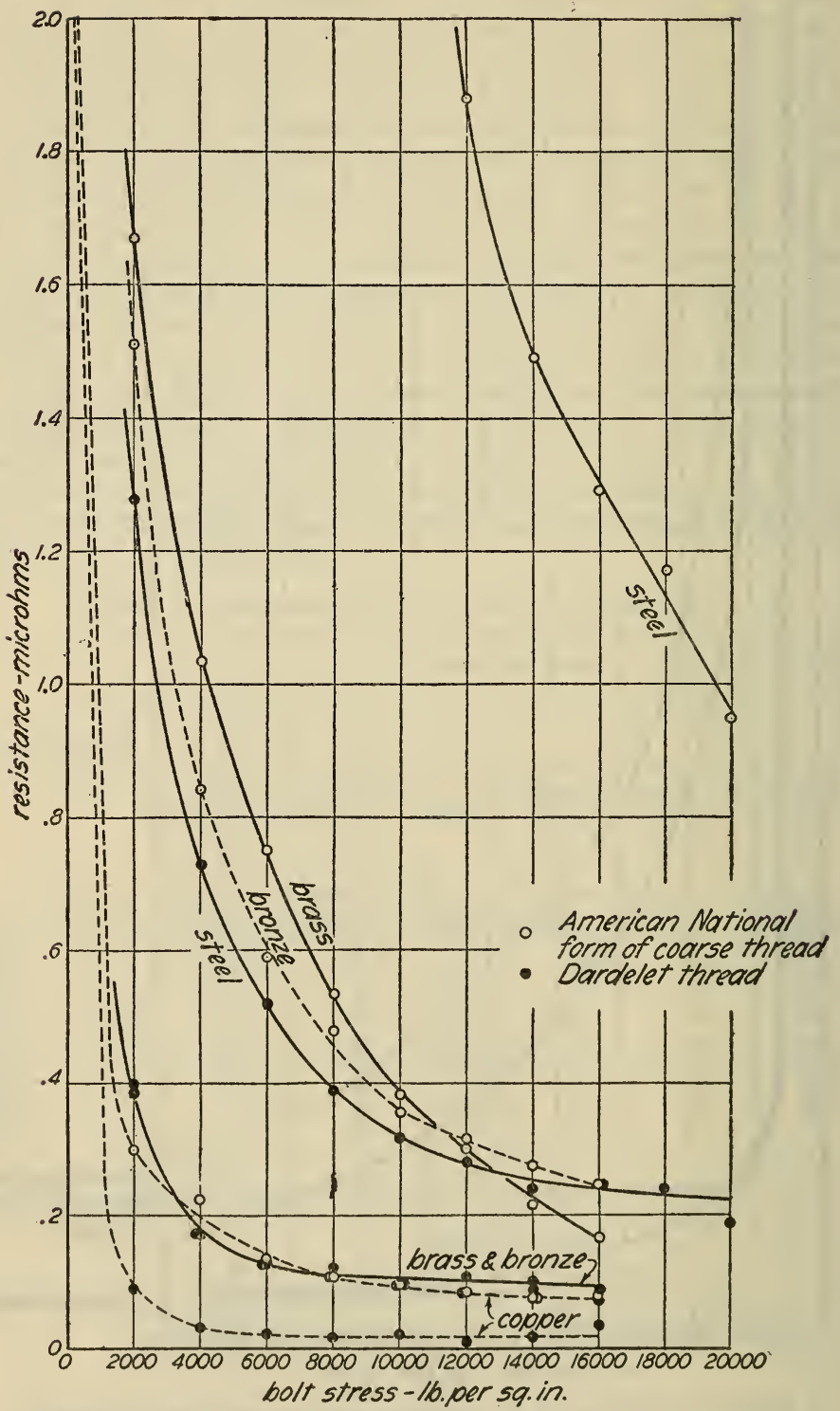

Figure 10.-Nut-to-bolt resistance tests on copper, bronze, brass, and steel 
$\mathrm{T}_{\mathrm{ABLE}}$ 3.-Contact resistance between nut and bolt

\begin{tabular}{|c|c|c|c|c|c|c|}
\hline \multirow{3}{*}{ Stress in bolt } & \multicolumn{6}{|c|}{ Contact resistance } \\
\hline & \multicolumn{3}{|c|}{ American National thread } & \multicolumn{3}{|c|}{ Dardelet thread } \\
\hline & $\begin{array}{l}\text { Brass } \\
\text { specimen } \\
\text { No. } 1\end{array}$ & $\begin{array}{c}\text { Brass } \\
\text { specimen } \\
\text { No. } 2\end{array}$ & Average & $\begin{array}{l}\text { Brass } \\
\text { specimen } \\
\text { No. } 1\end{array}$ & $\begin{array}{l}\text { Brass } \\
\text { specimen } \\
\text { No. } 2\end{array}$ & A verage \\
\hline $\begin{array}{c}\quad \text { Lbs./in. }{ }^{2} \\
0,000 \\
4,0000 \\
8,000\end{array}$ & $\begin{array}{c}\text { Michroms } \\
55.18 \\
1.45 \\
.74 \\
.53 \\
.34\end{array}$ & $\begin{array}{c}\text { Michroms } \\
11.18 \\
1.89 \\
1.33 \\
.97 \\
.73\end{array}$ & $\begin{array}{c}\text { Michroms } \\
33.18 \\
1.67 \\
1.04 \\
.75 \\
.535\end{array}$ & $\begin{array}{c}\text { Michroms } \\
\text { 12. } 78 \\
.358 \\
.160 \\
.131 \\
.116\end{array}$ & $\begin{array}{c}\text { Michroms } \\
15.08 \\
.42 \\
.18 \\
.131 \\
.116\end{array}$ & $\begin{array}{c}\text { Michroms } \\
13.93 \\
.389 \\
.170 \\
.131 \\
.116\end{array}$ \\
\hline $\begin{array}{l}10,000 \\
12,000 \\
14,000 \\
16,000\end{array}$ & $\begin{array}{l}.244 \\
.228 \\
.18 \\
.142\end{array}$ & $\begin{array}{l}.53 \\
.373 \\
.254 \\
.195\end{array}$ & $\begin{array}{l}.387 \\
.301 \\
.217 \\
.169\end{array}$ & $\begin{array}{l}.101 \\
.101 \\
.096 \\
.086\end{array}$ & $\begin{array}{l}.096 \\
.067 \\
.081 \\
.06\end{array}$ & $\begin{array}{l}.099 \\
.084 \\
.089 \\
.073\end{array}$ \\
\hline
\end{tabular}

TABLE 4.-Contact resistance between nut and bolt

\begin{tabular}{|c|c|c|c|c|c|c|}
\hline \multirow{3}{*}{ Stress in bolt } & \multicolumn{6}{|c|}{ Contact resistance } \\
\hline & \multicolumn{3}{|c|}{ American National thread } & \multicolumn{3}{|c|}{ Dardelet thread } \\
\hline & $\begin{array}{l}\text { Copper } \\
\text { specimen } \\
\text { No. } 1\end{array}$ & $\begin{array}{c}\text { Coppor } \\
\text { specimen } \\
\text { No. } 2\end{array}$ & Average & $\begin{array}{l}\text { Copper } \\
\text { specimen } \\
\text { No. } 1\end{array}$ & $\begin{array}{l}\text { Copper } \\
\text { specimen } \\
\text { No. } 2\end{array}$ & A verage \\
\hline $\begin{array}{c}\text { Lbs./in.2 } \\
0,000 \\
4,000 \\
6,000 \\
8,000\end{array}$ & $\begin{array}{c}\text { Michroms } \\
24.9 \\
.27 \\
.24 \\
.127 \\
.108\end{array}$ & \begin{tabular}{|c|} 
Michroms \\
9.3 \\
.33 \\
.21 \\
.141 \\
.104
\end{tabular} & $\begin{array}{c}\text { Michroms } \\
17.1 \\
.30 \\
.225 \\
.134 \\
.106\end{array}$ & $\begin{array}{c}\text { Michroms } \\
1.67 \\
.084 \\
.036 \\
.036 \\
.021\end{array}$ & $\begin{array}{c}\text { Michroms } \\
2.91 \\
.093 \\
.029 \\
.007 \\
.002\end{array}$ & $\begin{array}{c}\text { Michroms } \\
2.29 \\
.088 \\
.033 \\
.022 \\
.012\end{array}$ \\
\hline $\begin{array}{l}10,000 \\
14,000 \\
16,000\end{array}$ & $\begin{array}{l}.093 \\
.074 \\
.069 \\
.060\end{array}$ & $\begin{array}{l}.093 \\
.093 \\
.088 \\
.098\end{array}$ & $\begin{array}{l}.093 \\
.083 \\
.078 \\
.079\end{array}$ & $\begin{array}{l}.021 \\
.011 \\
.011 \\
.036\end{array}$ & $\begin{array}{l}.023 \\
.007 \\
.018 \\
.029\end{array}$ & $\begin{array}{l}.022 \\
.009 \\
.015 \\
.033\end{array}$ \\
\hline
\end{tabular}

\section{DISCUSSION OF RESULTS}

For stresses of 2,000 or more lbs./in. ${ }^{2}$ in the bolts, the contact resistance between nuts and bolts is small, and that of the Dardelet thread is much smaller than that of the American National coarse thread. The highest resistance shown on the graph corresponds to the resistance of about an inch length of the body of the bolt.

It should be remembered that these threads were well oiled. Experience with different types of sliding electrical contacts shows that usually the electrical resistance when oiled is about one-tenth the electrical resistance when dry.

The contact resistance is lower with those materials having lower electrical resistivity; that is, having higher electrical conductivity. However, for otherwise similar conditions all of the observed differences in the contact resistance can not be accounted for on this basis.

We have defined the contact resistance as the difference in the electrical resistance of two specimens of the same material and dimensions, one being solid and the other consisting of two pieces (nut and 
bolt). The idle faces and parts of the tops and bottoms of the threads can not be in electrical contact. Further, since these nuts and bolt had threads of commercial quality, with somewhat rough surfaces as may be seen by reference to Figures 2, 3, and 4, all of that part of the surface supporting the load may not have been in electrical contact. However, with the same load the area in contact was, no doubt, greater in the case of the softer materials than in the case of the steel and greater with Dardelet than with American National threads. As the stress in the bolt was increased by turning the nut, it is easily understood that the area in electrical contact would be increased even to the point of being equal to that of the supporting surface if the stress could be made sufficiently great. This is at least a logical explanation as to why the contact resistance is lower with soft than with hard materials, lower with Dardelet than with American National threads, and tends toward a minimum rather than a zero value as the stress in the bolts is increased.

The extent to which the results given in this paper would apply under radically different conditions can not be estimated.

\section{ACKNOWLEDGMENTS}

The authors wish to express their appreciation and thanks to Prof. H. L. Whittemore, chief of the engineering mechanics section, and to Dr. L. B. Tuckerman, assistant chief of mechanics and sound division, both of the Bureau of Standards, for their cooperation in this investigation.

\section{CONCLUSIONS}

1. The electrical contact resistance (between nut and bolt) decreases as the stress in the bolt increases and becomes nearly constant as the stress approaches the yield point of the material.

2. For bolts of the same size and material under equal stresses in the bolt, the contact resistance (between nut and bolt) of the American National coarse thread is, in general, more than four times the corresponding resistance of the Dardelet thread.

3. With oiled Dardelet threads on three-fourths-inch bolts under stresses of 4,000 or more lbs./in. ${ }^{2}$, applied by turning the nuts on the bolts, the contact resistances between nuts and bolts are less than the resistances of an one-eighth inch length of the bodies of the bolts.

Washington, June 20, 1930. 